\title{
Repositioning of Africa in knowledge production: shaking off historical stigmas - introduction
}

\author{
Juliet Thondhlana and Evelyn Chiyevo Garwe
}

Abstract: Africa is recognised as the cradle of humankind with a proven record of creativity and innovation as evidenced by its great empires and kingdoms. It is thus an enigma that currently Africa contributes only $2 \%$ to global knowledge production, a situation that is widely believed to account for its underdevelopment. Even though scholarly disagreement cuts very deep here, it is mostly due to the reasons of the status quo rather than to disputing the poor showing of Africa in global knowledge production. The high quality of articles presented in this supplementary issue showcases our conviction that Africa can indeed shake off historical stigmas and reposition itself as a giant in knowledge production. This editorial introduces the contributions in the issue which interrogates the status quo and explores ways in which knowledge production can be enhanced. Three key thematic approaches are presented: a decolonial approach to legitimising African knowledge based on its needs, culture, and heritage; development of robust knowledge production and quality assurance institutions; and inclusive education and knowledge production.

Keywords: Africa, knowledge production, inclusivity, decolonisation, sustainable development.

(C) The author(s) 2021. This is an open access article licensed under a

Creative Commons Attribution-NonCommercial-NoDerivs 4.0 Unported License 


\section{Setting the scene}

Although our interest in upscaling knowledge production in Africa started some time back (Organisational and Research Culture in African Universities multi-country project), it was not until the British Academy (BA) funded a three-day writing workshop that our cause was heightened. The workshop was organised by the Zimbabwe Council for Higher Education (ZIMCHE) in partnership with the University of Nottingham, and hosted by the University of Zimbabwe on 24-26 September 2019. Together with the forty workshop participants from six African countries (Ghana, Kenya, Nigeria, South Africa, Uganda, and Zimbabwe) and the seven journal editors representing the Global South and the Global North (South Africa, UK, Canada, USA), we committed ourselves to collaborate and further explore ways and interventions to overcome the barriers to African scholarly productivity and contribution to global knowledge conversations. Leveraging on this rich network, again with the support of the BA, our proposal to organise and run a 'thematic stream' at the African Studies Association UK (ASAUK) conference to further the debate on strengthening African research writing for publication was accepted. Although this conference was cancelled due to the COVID-19 outbreak, the Journal of the British Academy dedicated this supplementary issue to afford us the necessary publication space.

The quest for the survival of humankind makes knowledge production ubiquitous, such that wherever there is life, knowledge is produced and shared or transferred (Harari 2014). Societies the world-over have different cultures, environments, experiences, and ways of addressing problems according to their contextual realities (Matike 2008). Knowledge is thus local, partial, and fragmented (Kolawele 2012), and its generation and its utilisation are powerful engines of socio-economic growth and development (Gurak 2004). Using this assertion, some scholars have argued that Africa's underdevelopment is attributable to its meagre contribution (1-2\%) to global knowledge production (Makinda 2007, Fonn et al. 2018). Furthermore, Africa lacks indigenous theories, forcing it to uncritically adopt and apply scholarly resources of Western origin largely inapplicable to the real-life challenges in the African context (Kaya \& Seleti 2013). Yangni-Angate (2015: 45) articulates the continent's genius by its history as the 'Cradle of Humanity; Mother of civilization, Cradle of Sciences; and the Birthplace of Religions'. Africa consists of fifty-four sovereign nations, is centrally positioned for world trade, and has an abundance of human and natural resources (Ochola et al. 2010) 'estimated to be greater than that of almost any other continent in the world' (Nkrumah 1963: 216, Ndulu et al. 2007).

In this supplementary issue, we join other scholars (e.g., Gutto 2006) in critically engaging with the question, "how could this happen to the same Africa, recognised as the cradle of humankind (Beyin 2015), featuring great empires and kingdoms of 
artistic, technological, scientific, cultural, and material sophistication?' We postulate that Africa's renaissance and its industrialisation and modernisation lie in its ability to upscale its intellectual capital and reposition its knowledge systems to provide home-grown solutions guided by the pan-Africanism philosophy. To this end we acknowledge the growing number of scholars, thought leaders (past and present), and citizenry who have committed themselves to this cause by 'steadily incorporating anti-colonial, postcolonial or decolonial perspectives into their critical pedagogical praxis of researching, writing, teaching and mobilising' (Steinberg \& Down 2020: 186). Their voices, recommendations, policies, activities, thoughts, and reflections are key in pushing forward Africa's sustainable development. Cognisant that all knowledge systems are anchored in the local, and acknowledging the skewed power matrix attributed to colonialism and imperialism (see Ngugi wa Thiong'o 1986, Smith 2002), we discuss possible ways out of Africa's knowledge production conundrum. Empirical evidence in support of our position revealed potential in Africa's renaissance, citing, for example, the six countries that have registered economic growth figures in excess of $6 \%$ per year for the past six years (Economist 2011).

The major challenge faced by Africa is how to redeem itself from its present predicament, when the continent and its people remain 'trapped by the enduring colonial domination in their ways of knowing, seeing and imagining' (Ndlovu 2018: 95). According to Ndlovu,

this question is quite challenging, not only because colonial domination in the sphere of knowledge production has played a role of emptying the minds of African subjects of their knowledges and memories, but has also played a part in implanting foreign ways of knowing and remembering. (95)

The commitment to reposition Africa in the global knowledge economy can be traced back to the historic formation of the Organisation of African Unity (now the African Union), created in May 1963 towards embracing Pan-Africanism (unification/oneness/ integration/fraternity of Africa), to achieve the 'African Renaissance' and adopting 'African solutions to African challenges' (Molla \& Cuthbert 2018: 252). The blueprint to put Africa on the move (Ndizera \& Muzee 2018) is enshrined in the Agenda 2063 document (African Union Commission 2015). As Xercavins (2008) advises, the quality of the desired/preferred future is a function of the sum (total) of the present well-considered responses. This long-range reflection, anticipation, planning, and forecasting prepares nations and institutions for the future and is referred to as 'foresight' (Hammoud \& Nash 2014: 41). In this regard, Agenda 2063 is a 'foresight' blueprint and policy direction for Africa that is alive to the cause of promoting African scholarship as a means to achieving sustainable development. Thus, what is presently required for and by Africa is an articulation of the dynamics surrounding the 
desirability and preparedness of member countries to strategically create, share, and utilise knowledge (and the trajectories thereof) to generate goods and services necessary for sustainable development. This presents a challenge of developing and expanding knowledge institutions and scholars, especially in the backdrop of a multiplicity of other challenges relating to colonial baggage, policies, resources, as well as geopolitical inequalities of knowledge production.

We will begin by clarifying key and perhaps controversial concepts/terminology focusing on coloniality and its counter struggles, in the context of knowledge production from the issue editors and authors' standpoints, to enable a shared understanding with our audience.

1. Colonialism: The state wherein a people or nation loses political and economic sovereignty to another nation to the extent that they are controlled by that nation in every aspect of their lives and affairs. Colonialism in this way, draws equivalence with the concept of imperialism.

2. Coloniality: The continued imposition of epistemic, geographic, and psychological domination of power that transcend colonialism. To Maldonado-Torres (2007: 243) 'coloniality is maintained alive in books, in the criteria for academic performance, in cultural patterns, in common sense, in the self-image of peoples, in aspirations of self, and so many other aspects of our modern experience. In a way, as modern subjects we breathe coloniality all the time and every day.'

3. Decoloniality: The identification, unmasking, and dismantling of the forces that perpetuate an asymmetrical world to help build an inclusive future.

4. Postcoloniality: The discourse concerned with disrupting the biased global power relations arising from coloniality and give way to ethnic/racial/cultural hybridity, representation, respect, and interdependence. In this respect, the decolonial project is well embedded in the postcolonial agenda. The point of departure of the two concepts, according to Ndlovu-Gatsheni (2016), is that decoloniality unravels historical precolonial and colonial issues in its contextualisation of present power imbalances.

5. Academic imperialism: Explicit and subtle domination of people or nations by another in their way of knowing, thinking, and knowledge.

6. Globalectics: A holistic way of thinking that encompasses inclusivity, interconnectedness, and equality of all humanity and nations of the world. 


\section{Seminal scholars on increasing knowledge production in Africa for sustainable development}

At this juncture we pay tribute to African scholars who have provided thought leadership to enable Africa to break out from what Mkandawire (1997) describes as 'closed' discursive and practical spaces. In his piece, he explains that 'closed' means that African scholars are victims of exclusion and marginalisation from 'global' epistemic canons, and economic and political arenas. By engaging in such brave scholarly acts of empowerment, these authors struggle to liberate Africa from the usurpation of its knowledge, political, and economic autonomy against resistance from both local and external forces. As alluded to by Arowosegbe (2019: x), showcasing such luminary figures contributes to 'understanding the problematic underpinnings of Africa's contradictory trajectory, and also for transcending its historic intellectual lag in the area of knowledge production'. The list of these thought leaders consists amongst others of the following: Ali Mazrui, Amina Mama, Claude Ake, Frantz Fanon, Joseph Ki-Zerbo, Mahmood Mamdani, Ngugi wa Thiong'o, and Thandika Mkandawire (Gumede 2014). In this issue, Crawford et al. (2021) outline the reflections and analysis of a number of postcolonial and decolonial scholars, who have contributed to the attempts to liberate Africa from the shackles of coloniality and epistemic injustices that continue to influence knowledge production on Africa and elsewhere in the Global South. In this editorial, we briefly discuss the contributions from three key African academics, Claude Ake, Joseph Ki-Zerbo, and Ngugi wa Thiong'o.

Claude Ake, a renowned political scientist and philosopher, was born on 18 February 1939 in Omoku, Nigeria. He died in a plane crash on 7 November 1996. Ake's major contribution was in advocating for Africa's development to be driven from within, leveraging on indigenous knowledge, thus challenging Africans to find local solutions to Africa's problems. Ake was a critic of Eurocentricism and the practice of dividing the world into North and South, opting for a situation characterised by non-hierarchical, cross-cultural intercourse in knowledge production. His notable works are: A Theory of Political Integration (1967), Revolutionary Pressures in Africa (1978), Social Science as Imperialism: The Theory of Political Development (1979), A Political Economy of Africa (1981), 'The Future of the State in Africa' (1985), Democracy and Development in Africa (1996), and The Feasibility of Democracy in Africa (2000).

Joseph Ki-Zerbo (1922-2006), was an educationist and historian born in Burkina Faso. Irked by the fact that ' $85 \%$ of research on Africa is conducted outside Africa' (Ki-Zerbo 1992), Ki-Zerbo sought to inspire Africans towards freedom, identity, creativity, imagination, and a home-grown or self-made approach to education and development. Joseph Ki-Zerbo is credited (along with Claude Ake, and Ngugi wa 
Thiong'o) with propounding the theory of 'endogenous development' anchored on principles of pan-Africanism. Some of Ki-Zerbo's key literary pieces include: History of Black Africa (1978), Educate or Perish: Africa's Impasse and Prospects (1990), and Other People's Mats (1992).

Ngugi wa Thiong'o, an African writer and scholar of note, was born on 5 January 1938 in Limuru, Kenya. He exercises his influence through his essays, novels, journalism, plays, and social activism to showcase how language can enable Africans to think reflectively and produce knowledge. To Ngugi, the exclusion of vernacular languages from most African education systems, apart from being oppressive, also aids in colonisation of the mind (Ngugi wa Thiong'o 1986, 1993). He also proposes how colonial languages can be used in Africa's decolonial project (Ngugi wa Thiong'o 2016)

The articles in this supplementary issue explore the impediments to improved scholarship, discuss emerging and innovative methods/models, and recommend evidence-based solutions as part of Africa's decolonial knowledge production project. Cognisant of the wisdom of Ki-Zerbo (2003) that no one approach or discipline can endeavour to address the complex and intricate reality of the African context, we embrace a multi-pronged and multidisciplinary analytical framework. The issue comprises twelve contributions exhibiting plurality in thematic foci, conceptualisation, and contextual, methodological, gendered, and disciplinary approaches. The philosophical, theoretical, discursive, descriptive, critical, evaluative, comparative, and empirical articles reflect on the history, context, and status quo, and recommend a three-way forward thematic approach to the project of repositioning Africa's knowledge production.

Although some of the articles have overlapping concepts, ideas, and solutions, this editorial groups and introduces them under the three approaches to the way forward. The first approach suggests a decolonial approach to legitimising African knowledge based on its needs, culture, heritage, and contribution to the global knowledge system to address the continent's historical and colonial dogmas. The second approach focuses on the development of robust knowledge production and quality assurance institutions that engender strong research cultures and good researcher integrity. The third and final approach seeks to promote inclusive education and knowledge production.

\section{Decolonising Africa's research, innovation and development}

The negative influence of colonialism on Africa's knowledge production is well acknowledged (Mazrui 2000). Colonialism privileged the Western world-view, institutions, knowledges, languages, and value systems at the expense of African 
epistemologies (Olukoshi 2007). It is now long after African nations gained independence, and yet the Western colonial legacies continue to cast their shadows on the African knowledge production arena, anticipating, shaping, informing, and dictating the pace. Due to the 'colonial global' knowledge production matrix, Africa is dependent on international publishing infrastructures and requires the West to legitimise its knowledge production. Referring to the publication statistics (based on largely Western highly ranked journals) used to measure Africa's knowledge production, Keim (2008: 32) explains, 'African scholarly production is oriented neither towards the local peers nor to one's own society, but towards the overseas public.' It is widely acknowledged that the major players in academic publishing are the United Kingdom and the United States, both accounting for more than half of the world's indexed journals (Graham et al. 2011). In addition, in those leading journals, the majority of contributions relating to African issues are written by non-African writers, a phenomenon that Mama (2007) finds deplorable.

The three articles that speak to the decolonial approaches to knowledge production contribute individually and collectively to scholarly efforts (e.g. Ngugi wa Thiong'o 1986) aimed at addressing the Western hegemony inherent in African knowledge and education systems by propelling the African epistemic legitimacy to the world.

The first contribution under this theme, 'Decolonising Knowledge Production on Africa: Why It's Still Necessary and What Can Be Done' by Crawford et al. (2021), extensively reviews the canon of literature on the marginalisation of African scholarship due to asymmetrical power relations between researchers in the Global North and South. It then proposes practical ways to challenge/counter the status quo. The article rises to another level by further reflecting on the practical solutions and rendering them desirable but insufficient, thereby calling for more profound solutions. The suggested point of departure involves (re)discovering alternative ways of understanding the world through incorporating the marginalised voices. This involves reorienting the methodological, ontological, and epistemological frameworks by, for example, 'rethinking thinking' (Ndlovu-Gatsheni 2018), creating 'ecologies of knowledge' and 'epistemologies of the South' (Santos 2007). The article concludes by advocating a decolonial methodology that favours participatory/inclusive approaches to mainstream knowledge production.

The second article, entitled 'Revisiting (Inclusive) Education in the Postcolony' by Abdulrahman et al. (2021), uses a dialogic relational reflexive methodology (Hibbert et al. 2014) to argue for inclusive education and knowledge production. The use of a metalogue as a methodological approach allows the contributors to jointly ponder the issues from different perspectives and positionalities, and in a way that honours their individual voices. The four contributors to the metalogue proffer diverse perspectives and positionalities which are rich in possible solutions applicable to 
postcolonial contexts. By critically questioning and analysing issues from different standpoints, all contributors agree that historical and contextual aspects should inform inclusive education for it to be fit for purpose. The prevailing situation wherein African education largely fails to address societal challenges (with some scholars attributing it to the presence of universities in Africa instead of African universities) should pave the way for the 'time for Africa'. The term 'universities in Africa' refers to a situation whereby the curriculum they follow 'imitates with a high degree of exactitude Western universities' academic curricula objectives, content, assessment approaches and learning materials' (Fredua-Kwarteng 2019). The desired position is to have 'African universities' which address solutions to African problems and share best practices with the whole world. Confidence and concerted efforts towards creating and incorporating indigenous African knowledge are critical, whilst contesting the colonial stereotyping, prejudices, and mental ascriptions of inferiority to western knowledge (Wright et al. 2007). The contributions to this metalogue point to the intractability of some of the educational challenges of the continent, including patterns of exclusion that defy simplistic definition and resolution. In the absence of neat answers or trite recommendations, we argue for ongoing difficult and critical conversations, across contexts and across disciplines.

The third contribution, 'Internationalisation of Higher Education for Pluriversity: A Decolonial Reflection' by Ndlovu-Gatsheni (2021), advances the need for a decolonial approach to the internationalisation of higher education (IHE). The article argues that the current IHE agendas are largely Euro-centric and are motivated by academic capitalism, university imperialism, and market fundamentalisms. The article advances the centrality of diverse loci of enunciation of knowledge and education to enable a richer world-sensing and to enhance people's self-understanding in relationship to other selves in the universe. Such an internationalisation of higher education is predicated on recognition of diverse ways of human knowing through which different people interpret and make sense of the world. The university thus assumes a new name - pluriversity - effectively removing the notion of it being universal(ly Western) into being inclusive and plural as informed by practices of globalectics and coexistence of particularities. Globalectics implies a plural uniform world without a single pivot: any point is equally a centre, thereby embracing wholeness, interconnectedness, and equality (Santos \& Meneses 2020).

Puplampu (2021) posits that Africa can learn valuable lessons from Western colonisers who used knowledge (for example, in psychology, culture, religion, trade, and the military) strategically and systematically to completely colonise Africa. $\mathrm{He}$ argues that, in the first instance, Africans must be inward-looking, focused, and coordinated in their decolonial project and development agendas. However, he sees the ultimate and desired goal being achieved when there is a global demand for 
African knowledge. In supporting this assertion, Garwe et al. (2021) add that through the recent interface with the COVID-19 pandemic, it became clear that the challenge of coming up with a cure is not limited to any specific nation or region but is a global task. Thus the world is ready for inclusive global knowledge solutions which NdlovuGatscheni (2021) refers to as 'pluriversity'. If Africa can distinguish itself through such scientific contributions, then it will have reached its goal of repositioning itself as a reputable source of knowledge with global impact.

\section{Develop robust internationalised higher education and quality assurance institutions}

The first contribution in this section of the issue, on 'What Can the African Diaspora Contribute to Innovation and Knowledge Creation?' by Thondhlana et al. (2021), echoes calls for engaging diasporas in sustainable development of economies in the developing world through the production of knowledge and knowledge economies (Leung 2015). It recognises the more recent emergence of transnationalism as a new form of migration which has evidenced capacity to turn a brain drain pattern of subtractive migration into brain circulation for the mutual benefit of both countries of origin and host countries, in a context of the global war of talent where host Global North countries have been strategically positioned to benefit from the 'best and brightest' of the Global South. Given the phenomenal growth of the collective African diaspora in recent times, the causes, courses, consequences, and implications of this growth in Africa and on African knowledge production are a subject begging systematic and intensive exploration (Zeleza 2005). Using the example of Zimbabwe and drawing from five case examples of diaspora transnationals with evidenced contribution to knowledge production, innovation and development activity in Zimbabwe, the article explores their lived experiences to understand emerging patterns. To this end, the article presents emerging models of diaspora participation in knowledge production. In doing so, the article also explores the role played by colonial and postcolonial projects in constructing and shaping knowledge production, and demonstrates how the models are challenging historical stigmas.

The second contribution, on 'Evaluation of a Quality Assurance Framework for Promoting Quality Research, Innovation and Development in Higher Education Institutions' by Garwe et al. (2021), recognises the centrality of national quality assurance frameworks in promoting quality research and innovation. The authors use the quality assurance methodology of self-evaluation and peer review to suggest how national quality assurance bodies can improve the quantity and quality of research and development in higher education institutions. The key areas of intervention 
include (a) relevant national policies, standards, and guidelines; (b) doctoral training; (c) research capacity strengthening; (d) institutional research support units; (e) robust performance management featuring performance measures and targets; (f) establishment of effective structures manned with professional staff to support, manage, and promote research; $(\mathrm{g})$ collaborations, partnerships to promote a firm international grounding; and (h) investment in research resources.

The third contribution, on 'Doctoral Training in African Universities: Recent Trends, Developments and Issues' by Jowi (2021), further buttresses Garwe et al.'s (2021) point that the major challenge facing African universities relates not only to their cultures and researcher behaviour (Puplampu 2021), but also to their limited research capacities. The article attributes this situation in part to the low numbers of academics with doctorates, which also compounds the problem as this leads to low doctoral graduate outputs. The article analyses Africa's position (challenges and progress) regarding doctoral training and the implications thereof. The article draws from empirical data from a collaborative project featuring African and European partners and covering six African countries. The increase in doctoral programmes and enrolments predicts an optimistic future for doctoral training and research in Africa. Again the article highlights importance of national research quality assurance frameworks in steering the behaviour of universities, industry, and government (Garwe et al. 2021).

In the fourth article, on 'Tackling the Behavioural Aspects of Knowledge Production: Research Culture, Behavioural Intentionality and Proactive Agenda Setting by Scholars in Africa', Puplampu (2021) advocates critical examination of the actions, behaviours, and institutionalised agendas antecedent to and concomitant to producing credible knowledge in line with their own agendas, and thus being able to 'tell their own story'. The article rejects the continued misrepresentation of the continent as Africa which gives an impression of an undifferentiated mass. It draws parallel to the well-recognised usage of the term 'the Americas' (Burchfield 2004), and suggests adoption of the term 'the Africas' in reference to the African continent, to emphasise the cultural, human, political, and geographical diversity of the continent and its islands. The article argues that the contested, challenged, and colonialised knowledge space requires that scholars have to break down walls and commit to collaborative and joint knowledge production through co-creating, co-sharing, and co-validating. The knowledge actors need to wake up to the reality that, as long as the market and economic dimension of knowledge is not harnessed, much income is being lost. There are intellectual, utilitarian, pecuniary, and instrumental reasons why the resurgence of Africa in the knowledge process is a matter of economic survival. 


\section{Inclusive education and knowledge production}

As intimated by Ribbins (2006), exclusive knowledge foundations have shaped that which we claim to know about knowledge and how we know it. The contributions to this thematic approach, although not exhaustive in themselves, argue for a democratic and comprehensive approach to improving knowledge production in Africa. Inclusivity facets of knowledge production and dissemination herein captured relate to gender, methodology, geography, and vulnerable groups.

The first contribution in this section of the issue, on 'Gender and Knowledge Production in Institutions of Higher Learning: An African Context' by Zvavahera et al. (2021), consolidates and extends the need to address the gendered nature of the knowledge economy and society (Walby 2011). The article employs a multi-country cross-sectional survey methodology and goes beyond substantiating the factors and extent of gender inequality in knowledge production, and recommends ways of narrowing the gap. The findings showed that African women had limited exposure to the knowledge economy due to issues of access to higher education and research grants. The recommendations range from policy to practical interventions to fully support female researchers in knowledge production.

The thesis of the second article, 'Digital Historical Research and the Repositioning of Africa in Knowledge Production' by Kusena \& Zhou (2021), is that methodologies play a key role in knowledge production, particularly with regards to the history discipline. The article articulates the challenges brought about by the current overreliance on the use of centralised state archives, and discomfort by scholars in embracing digital sources of data. The recent COVID-19 scourge has challenged the research landscape, pushing historians to rethink their apprehension of digital sources of data. The article calls upon history scholars to embrace digitised data sources to bypass the bureaucracy and other legal complexities of traditional methods of data collection and knowledge dissemination. The digital knowledge dissemination pathway has potential to propel the resurgence of African knowledge to economic prosperity.

The third article, on 'Geopolitical Diversity in Occupational and Organisational Psychology: Shaking Off Historical Comforts and Confronting Real-world Challenges' by Puplampu \& Lewis (2021), reveals similar exclusionary tendencies in the occupational and organisational psychology (OOP) discipline. The authors explore the advances and highlight the major limitation of the field regarding the lack of diversity in the geopolitical and international sources of OOP theory. Although the OOP theory and tools originated from the West, it finds universal application even in regions with different historical, cultural, political, socio-economic, and philosophical traditions and contexts. This article argues that to migrate theory and research into impactful practice — globally_OOP must engage a deliberate process of fostering 
alternative, autochthonous, and indigenous knowledge from geopolitical areas which are under-represented. The article proposes corrective actions and agendas which would assist OOP to become more diverse and support the growth of Africa's contribution to global knowledge production in the work and organisational sciences.

The article recommends that OOP ought to learn from its own tenet of the need for diversity and inclusivity in institutions/corporations, applying the same diversity to itself (Groggins \& Ryan 2013). Cognisant, from history lessons, that taking the recommended route is a conscious option, the authors question the desirability and feasibility of OOP practitioners to 'shake off historical comforts and bend their energies to the real-world problems that confront more than $80 \%$ of the global population'.

The fourth contribution, on 'Internally Displaced Persons and COVID-19: A Wake-up Call for African Solutions to African Problems - the Case of Zimbabwe' by Madziva et al. (2021), puts vulnerable communities particularly internally displaced persons (IDPs) into context. In support of Facer et al. (2020), the article argues for inclusive COVID-19 responses rather than the current one-size-fits-all Eurocentric approach. The article advances the need for African solutions to African problems, especially considering the fact that the global COVID-19 pandemic has threatened the capacity of the developed world to support developing countries. The process of inclusion of IDPs necessitates a robust demand for knowledge production that responds to the demands of the society. However, it is those local solutions that can rock the global scene: for instance, a COVID-19 cure could easily come out of Africa.

\section{Concluding remarks}

This supplementary issue, although not exhaustive, allows for African voices to be added to the knowledge production and knowledge economies conversations. This is critical not only in reviving African theorisation in ways that makes Africa take its place in finding solutions to global challenges. Africa is argued to be rich, not only in natural resources that have contributed towards enriching the economies of other continents and nations over the years, but also in indigenous knowledges (barely tapped) about how those resources can be harnessed to tackle some of the world's enduring human struggles. The articles in this issue explore the diverse ways in which the dearth in African knowledge production can be tackled, and in the process suggest promising approaches to upscale African knowledge economies and accelerate the continent towards new horizons. It is our hope that the contributions will provoke debate around the world and encourage more African diaspora knowledge economists 
and innovators to come out and participate in transnationalism for the enrichment of the continent.

\section{References}

Abdulrahman, H.K., Adebisi, F., Nwako, Z. \& Walton, E. (2021), 'Revisiting (Inclusive) Education in the Postcolony', Journal of the British Academy, 9(s1), 47-75.

https://doi.org/10.5871/jba/009s1.047

African Union Commission (2015), Agenda 2063: The Africa We Want (Addis Ababa, African Union). http://www.agenda2063.au.int/en/home

Ake, C. (1967), A Theory of Political Integration (Homewood, IL, Dorsey Press).

Ake, C. (1978), Revolutionary Pressures in Africa (London, Zed Books).

Ake, C. (1979), Social Science as Imperialism: The Theory of Political Development (Ibadan, Ibadan University Press).

Ake, C. (1981), A Political Economy of Africa (Harlow, Longman).

Ake, C. (1985), 'The Future of the State in Africa', International Political Science Review, 6(1): 105-14. https://doi.org/10.1177/019251218500600111

Ake, C. (1996), Democracy and Development in Africa (Washington, DC, The Brookings Institution).

Ake, C. (2000), The Feasibility of Democracy in Africa (Dakar, CODESRIA).

Arowosegbe, J. (2019), Claude Ake: The Making of an Organic Intellectual (Grahamstown, AHP Publications)

Beyin, A. (2015), 'Human Origins, Dispersal and Associated Environments: An African Perspective', in Ethnology, Ethnography and Cultural Anthropology (Encyclopedia of Life Support Systems; Paris, UNESCO \& EOLSS Joint Committee).

Burchfield, R. (2004), America (New York, Oxford University Press).

Crawford, G., Mai-Bornu, Z. \& Landström, K. (2021), 'Decolonising Knowledge Production on Africa: Why It's Still Necessary and What Can Be Done', Journal of the British Academy, 9(s1), 21-46. https://doi.org/10.5871/jba/009s1.021

Economist (2011), 'Africa's Hopeful Economies', 3 December 2011.

Facer, K., Lotz-Sisitka, H., Wals, A., Batra, P., McGrath, S., Mitchell, R., Ogbuigwe, A., Tikly, L., Tusiime, M. \& Vogel, C. (2020), 'The Case for Transformative Public Education: Responding to COVID-19 Now While Addressing Long-term Underlying Inequalities' (Transforming Education for Sustainable Futures). https://doi.org/10.5281/zenodo.3778587

Fonn, S., Ayiro, L.P., Cotton, P., Habib, A., Mbithi, P.M.F., Mtenje, A., et al. (2018), 'Repositioning Africa in Global Knowledge Production', Lancet, 392(10153): 1163-6. https://doi.org/10.1016/S0140-6736(18)31068-7

Fredua-Kwarteng, E. (2019), 'African Universities-Imitation or Adaptation?', University World News, 12 December 2019.

Garwe, E.C., Thondhlana, J. \& Saidi, A. (2021), 'Evaluation of a Quality Assurance Framework for Promoting Quality Research, Innovation and Development in Higher Education Institutions in Zimbabwe', Journal of the British Academy, 9(s1), 127-57. https://doi.org/10.5871/jba/009s1.127

Graham, M., Hale, S.A. \& Stephens, M. (2011), Geographies of the World's Knowledge ed. C.M. Flick (London, Convoco).

Groggins, A. \& Ryan, A. (2013), 'Embracing Uniqueness: The Underpinnings of a Positive Climate for Diversity', Journal of Occupational and Organisational Psychology, 86(2): 264-82. https://doi.org/10.1111/joop.12008 
Gumede, V. (2014), 'Thought Leadership, Thought Liberation, and Critical Consciousness for Africa's Development and a Just World', inaugural professorial lecture presented at the University of South Africa, Pretoria, South Africa.

Gurak, H. (2004), On Productivity Growth (Stockholm, ICS).

Gutto, S.B.O. (2006), 'Towards a New Paradigm for Pan-African Knowledge Production and Application in the Context of the African Renaissance', International Journal of African Renaissance Studies, 1(2): 306-23. https://doi.org/10.1080/18186870608529722

Hammoud, M.S. \& Nash, D.P. (2014), 'What Corporations Do With Foresight', European Journal of Futures Research, 2: 42. https://doi.org/10.1007/s40309-014-0042-9

Harari, Y. (2014), Sapiens: A Brief History of Humankind (Toronto, McClelland \& Stewart).

Hibbert P., Sillince J., Diefenbach T. \& Cunliffe A.L (2014), 'Relationally Reflexive Practice: A Generative Approach to Theory Development in Qualitative Research', Organizational Research Methods, 17(3): 278-98. https://doi.org/10.1177/1094428114524829

Jowi, J.O. (2021), 'Doctoral Training in African Universities: Recent Trends, Developments and Issues', Journal of the British Academy, 9(s1), 159-81. https://doi.org/10.5871/jba/009s1.159

Kaya, H.O. \& Seleti, Y.N. (2013), 'African Indigenous Knowledge Systems and Relevance of Higher Education in South Africa', International Education Journal: Comparative Perspectives, 12(1): $30-44$.

Keim, W (2008), 'Social Sciences Internationally — The Problem of Marginalisation and its Consequences for the Discipline of Sociology', African Sociological Review, 12(2): 22-48. https://doi.org/10.4314/asr.v12i2.49833

Ki-Zerbo, J. (1978), Histoire de l'Afrique noire [History of Black Africa] (Paris, Editions Hatier).

Ki-Zerbo, J. (ed.) (1990), Educate or Perish: Africa's Impasse and Prospects (Dakar-Abidjan, UNESCO-UNICEF).

Ki-Zerbo, J. (1992), La natte des autres (pour un développement endogène en Afrique) [Other People's Mats (For an Endogenous Development in Africa)] (Proceedings of the symposium of the Research Centre for Endogenous Development (CRDE); Paris, CODESRIA/Karthala).

Ki-Zerbo, J. (ed.) (2003), UNESCO General History of Africa, Vol.1: Methodology and Prehistory (Oxford, James Currey).

Kolawole, O.D. (2012), 'Intersecting Western and Local Knowledge: Critical Issues for Development Research in Africa', Journal of Knowledge Globalization, 5(2): 1-23.

Kusena, B. \& Zhou, M. (2021), 'Digital Historical Research and the Repositioning of Africa in Knowledge Production', Journal of the British Academy, 9(s1), 243-55. https://doi.org/10.5871/jba/009s1.243

Leung, M.W. (2015), 'Engaging a Temporal-Spatial Stretch: An Inquiry into the Role of the State in Cultivating and Claiming the Chinese Knowledge Diaspora', Geoforum, 59: 187-96. https://doi.org/10.1016/j.geoforum.2014.06.008

Madziva, R., Thondhlana, J., Garwe, E.C., Murandu, M., Chagwiza, G., Chikanza, M. \& Maradzika, J. (2021), 'Internally Displaced Persons and COVID-19: A Wake-up Call for and African Solutions to African Problems-The Case of Zimbabwe', Journal of the British Academy, 9(s1), 285-302. https://doi.org/10.5871/jba/009s1.285

Makinda, S.M. (2007), 'How Africa Can Benefit from Knowledge', Futures, 39: 973-85. https://doi.org/10.1016/j.futures.2007.03.004

Maldonado-Torres, N. (2007), 'On the Coloniality of Being: Contributions to the Development of a Concept', Cultural Studies, 21(2-3): 240-70. https://doi.org/10.1080/09502380601162548

Mama, A. (2007), 'Is It Ethical to Study Africa? Preliminary Thoughts on Scholarship and Freedom', African Studies Review, 50(1): 1-26. https://doi.org/10.1353/arw.2005.0122

Matike, E. (2008), 'Knowledge and Perceptions of Educators and Learners in the Incorporation of IKS into School Curriculum', unpublished BA (Honours) thesis, North-West University, South Africa. 
Mazrui, Ali (2000), The African Renaissance: A Triple Legacy of Skills, Values and Gender (CBAAC occasional monographs 9; Lagos, Centre for Black and African Arts and Civilization).

Mkandawire, T. (1997), Shifting Commitments and National Cohesion in African Countries (Uppsala, Nordic Africa Institute).

Molla, T. \& Cuthbert, D. (2018), Re-imaging Africa as a Knowledge Economy, Journal of Asian and African Studies, 53(2): 250-67. https://doi.org/10.1177/0021909616677370

Ndlovu, M. (2018), 'Coloniality of Knowledge and the Challenge of Creating African Futures', Ufahamu: A Journal of African Studies, 40(2): 95-112.

Ndlovu-Gatsheni, S.J. (2016), The Decolonial Mandela: Peace, Justice and the Politics of Life (London, Berghahn Books). https://doi.org/10.2307/j.ctvgs0c16

Ndlovu-Gatsheni, S J. (2018), Epistemic Freedom in Africa (Abingdon, Routledge). https://doi.org/10.4324/9780429492204

Ndlovu-Gatsheni, S.J. (2021), 'Internationalisation of Higher Education for Pluriversity: A Decolonial Reflection', Journal of the British Academy, 9(s1), 77-98. https://doi.org/10.5871/jba/009s1.077

Ndizera, V. \& Muzee, H. (2018), 'A Critical Review of Agenda 2063: Business as Usual?', African Journal of Political Science and International Relations Review, 12(8): 142-54. https://doi.org/10.5897/AJPSIR2018.1114

Ndulu, B., Chakraborti, L., Lijane, L., Ramachandran, V. \& Wolgin, J. (2007), Challenges of African Growth: Opportunities, Constraints and Strategic Directions (Washington, DC, World Bank). https://doi.org/10.1596/978-0-8213-6882-4

Ngugi wa Thiong'o (1986), Decolonizing the Mind: The Politics of Language in African Literature (Oxford, James Currey).

Ngugi wa Thiong'o (1993), Moving the Centre: The Struggle for Cultural Freedoms (Oxford, James Currey).

Ngugi wa Thiong'o (2016), Secure the Base: Making Africa Visible in the Globe (London, Seagull Books).

Nkrumah, K. (1963), Africa Must Unite (London, Panaf Books).

Ochola O. W., Sanginga, P.C., Bekalo, I. (2010), Managing Natural Resources for Development in Africa (Nairobi, University of Nairobi Press).

Olukoshi, A. (2007), 'African Scholars and African Studies', in H. Melber (ed.), On Africa. Scholars and African Studies. Contributions in Honour of Lennart Wohlgemuth (Uppsala, Nordic Africa Institute), 7-22.

Puplampu, B.B. (2021), 'Tackling the Behavioural Antecedents of Knowledge Production: Research Culture, Behavioural Intentionality and Proactive Agenda Setting by Scholars in Africa', Journal of the British Academy, 9(s1), 183-213. https://doi.org/10.5871/jba/009s1.183

Puplampu, B.B. \& Lewis, C. (2021), 'Geopolitical Diversity in Occupational and Organisational Psychology: Shaking off Historical Comforts and Confronting Real-world Challenges', Journal of the British Academy, 9(s1), 257-84. https://doi.org/10.5871/jba/009s1.257

Ribbins, P. (2006), 'Inclusion as Exclusion: Knowledge and its Production in Special Education', in John Chi-Kin Lee \& Michael Williams (eds) School Improvement: International Perspectives (Nova Science Publishers), 1-13.

Santos, B. de S. (2007), 'Beyond Abyssal Thinking: From Global Lines to Ecologies of Knowledges', Review - Fernand Braudel Center, 30: 45-89.

Santos, B. de S. \& Meneses, M.P. (eds) (2020), Knowledges Born in the Struggle: Constructing the Epistemologies of the Global South (Abingdon, Routledge). https://doi.org/10.4324/9780429344596

Smith, A. (2002), 'Power and Hierarchy of Knowledge', Geoforum, 40(1): 230-48.

Steinberg, R. \& Down, B. (eds) (2020), The SAGE Handbook of Critical Pedagogies (London, Sage Publications). https://doi.org/10.4135/9781526486455 
Teasley, S.C. \& Butler, A. (2020), 'Intersecting Critical Pedagogies to Counter Coloniality', in S. Steinberg (ed.) The SAGE Handbook of Critical Pedagogies, vol. 3 (London, Sage), 186-204. https://doi.org/10.4135/9781526486455.n26

Thondhlana, J., Roda Madziva, R. \& Garwe, E.C. (2021), 'What Can the African Diaspora Contribute to Innovation and Knowledge Creation? The Case Study of Zimbabwean Innovators', Journal of the British Academy, 9(s1), 101-25. https://doi.org/10.5871/jba/009s1.101

Walby, S. (2011), 'Is the Knowledge Society Gendered?', Gender, Work and Organization, 18(1): 2-29. https://doi.org/10.1111/j.1468-0432.2010.00532.x

Wright, H.K., Nashon, S. \& Anderson, D. (2007), 'Rethinking the Place of African Worldviews and Ways of Knowing in Education', Diaspora, Indigenous and Minority Education, 1: 239-46. https://doi.org/10.1111/j.1468-0432.2010.00532.x

Xercavins, J. (2008), 'Higher Education and its Institutions and the Civilizational Paradigm Crisis: Reflections, Analysis and Proposals From the Perspective of a Forum of International Civil Society Organizations', in Higher Education in the World 3. Higher Education: New Challenges and Emerging Roles for Human and Social Development (Basingstoke, Palgrave Macmillan), 35-9.

Yangni-Angate, K.H. (2015), 'Africa, Cradle of Humanity; Challenges of Modern Day Africa; History of Cardiac Surgery', African Annals of Thoracic and Cardiovascular Surgery, 10(2): 43-65.

Zeleza, P.T. (2005), 'The Academic Diaspora and Knowledge Production in and on Africa: What Role for CODESRIA?', in T. Mkandawire (ed.) African Intellectuals: Rethinking Politics, Language, Gender, and Development (London, Zed Books), 209-34. https://doi.org/10.5040/9781350218147.ch-010

Zvavahera, P., Dikito-Wachtmeister, M., Pasipanodya, S., Mwenda, N.S. \& Achar, G.O. (2021), 'Gender and Knowledge Production in Institutions of Higher Learning: An African Context', Journal of the British Academy, 9(s1), 217-41. https://doi.org/10.5871/jba/009s1.217

\section{Notes on the authors}

Dr Juliet Thondhlana is Associate Professor in Education and Migration at the University of Nottingham. She researches and publishes on the interaction of language, migration, refugee education, higher education, employability, gender, and entrepreneurship as well as the role of faith. More recently she has conducted research on the internationalisation of higher education in the UK and in Zimbabwe, culminating in the development of a national policy framework for the internationalisation of higher education in Zimbabwe.

ORCID ID: https://orcid.org/0000-0002-4065-5103

juliet.thondhlana@nottingham.ac.uk

Professor Evelyn Chiyevo Garwe is the Deputy Chief Executive Officer for the Zimbabwe Council for Higher Education. She is a keen researcher and practitioner with expertise and experience in quality assurance, and strategic and project management. She researches around transformation and quality issues in all aspects of higher education, including leadership and governance, research, internationalisation, gender, and financing. She is also interested in the ways that inclusive education shapes 
the narratives regarding various stakeholders: for example, students, academics, and vulnerable societies.

ORCID ID: https://orcid.org/0000-0002-6111-8622

garweec@gmail.com

To cite the article: Juliet Thondhlana and Evelyn Chiyevo Garwe (2021), 'Repositioning of Africa in knowledge production: shaking off historical stigmas - introduction', Journal of the British Academy, 9(s1): 1-17.

DOI https://doi.org/10.5871/jba/009s1.001

Journal of the British Academy (ISSN 2052-7217) is published by

The British Academy, 10-11 Carlton House Terrace, London, SW1Y 5AH

www.thebritishacademy.ac.uk 
